\title{
Coping Ability at Mid-life in Relation to Genetic and Environmental Influences at Adolescence: A Follow-up of Swedish Twins from Adolescence to Mid-life
}

\author{
Anna-Lena Lange \\ Department of Human Development, Learning and Special Education, Stockholm Institute of Education, Sweden
}

\begin{abstract}
Erom 1964 to 1971, twins and singleton controls were followed from 10 to 16 years of age in Swedish schools. It was a nationally representative sample of 323 twin pairs, and 1193 classmate controls. In 1991 a follow-up was made of this sample with the purpose of investigating genetic influences on experienced family and school environments, as well as coping ability at the age of 35 . The follow-up also evaluated the relation between coping ability at mid-life and family environment, as well as coping ability and school environment at adolescence for males and females. Genetic influences on perceived family and school environments, as well as on self-reported coping ability, have been investigated by means of comparisons of $\mathrm{MZ}$ and $\mathrm{DZ}$ twin pairs. A stepwise linear regression analysis was performed to assess environmental influences on coping ability at mid-life. The findings indicated that coping ability at mid-life is influenced by both genetic and environmental factors. Different environmental factors were operating for males and females, however. The results demonstrate that early environmental factors and genetic disposition have a long-term effect on coping ability.
\end{abstract}

In a previous Swedish longitudinal twin study (the SLU study), genetic and environmental influences on mental and physical development were investigated (Fischbein, 1978, 1979). One of the major findings of the SLU study was suggestive evidence that the magnitude of genetic variance differed in two kinds of home environments. A more permissive and stimulating environment tended to increase genetic variance, while a restrictive and non-stimulating environment reduced it. The inference drawn was that the magnitude of genetic expression varied according to environmental permissiveness/restrictiveness in environmental stimulation/non-stimulation.

The SLU-study also found significant gender differences in the pace of growth during childhood and adolescence. On average, girls matured 2 years earlier than boys, despite great variation within each group (Tanner, 1978; WestinLindgren, 1979). That variation seems to be greater for boys than for girls. As early as during the fetal period, boys tend to be influenced more negatively than girls by problems in the surrounding environment (Alin Åkerman \& Fischbein, 1991). There is evidence, also, that such differences remain throughout childhood and adolescence (Bergman, 1978; Nordberg, 1994; Sundelin Wahlsten, 1991).
Twenty years later, a follow-up study of the original SLU-sample has been made. The main purpose of this follow-up was to investigate genetic and environmental influences on life situation and coping ability at mid-life after a 20 -year period.

The ability to cope with everyday problems, as well as with problems of major significance, varies for individuals. The development of personal and intellectual strength is associated with coping ability and is influenced by both genetic and environmental factors. The magnitude of these influences has been discussed by Baumrind (1993) and Scarr (1993). Baumrind (1993) emphasizes the importance of parental influences on children's development. The most destructive parental child raising patterns are authoritarian with excessive control and lack of warmth and affection, and neglectful with resentment and uninvolvement. Permissive parents generally have a warm, accepting, and child-centered attitude toward their child. These parents, however, do not require mature behavior from their children, but allow them to behave autonomously and independently. Baumrind argues in favour of authoritative parents who "actively shape their children's sense of efficacy and selfesteem, and enhance their scholastic performance by producing situations in which their child is effective, and by imparting positive messages about their child's qualities and competencies" (Baumrind, 1993, p. 1308). Parents can be taught, therefore, how to treat their children in more constructive ways. Recently, Stattin and Kerr (2000) have argued that it is not the active monitoring by parents, but rather disclosure by the child that yields relevant information influential in child rearing. The arguments of Stattin and Kerr suggest that child rearing is an interactive process, based on the behavior of both child and parents.

According to Scarr (1993), the variation in behavioral development depends on genotypic propensities, environmental opportunities, and the timing of experiences. Scarr

Address for correspondence: Anna-Lena Lange, Ph.D., Department of Human Development, Learning and Special Education, Stockholm Institute of Education, Box 47308100 74, Stockholm, Sweden. Email: anna-lena.lange@lhs.se 
(1992) maintains, however, that the genetic-environment correlation is so strong that the environments most parents provide for their children have few differential effects on their offspring.

An essential question is how genetic factors interact with the environment under specific circumstances. Bronfenbrenner and Ceci (1994) point to the need to identify the mechanisms through which genotypes are transformed into phenotypes. They enhance the importance of what they call "proximal processes" in the optimal development of children and youths. These processes occur over time. There is a mutual influence on the individual and the environment. In the process, the internal becomes external and reversed, and becomes transformed in the process. Optimal development, of course, includes different components - for instance, physical, cognitive or emotional development. Two substantial factors are, however, the ability to cope with everyday problems and the ability to experience one's life situation as comprehensible, manageable, and meaningful (Antonovsky, 1987).

Antonovsky (1987) enhanced the importance of what he called "coping ability" for optimal development and staying healthy in spite of external strain. For this purpose, he developed a scale which he calls The Sense of Coherence (SOC), which can be defined as measuring the extent to which a person finds life comprehensible, manageable, and meaningful. SOC is an integral part of coping ability and, according to Antonovsky, is developed quite early in life. Whether the outcome of coping ability will be negative, neutral, or positive depends on the actual situation and how well the coping strategies of the individual will work to master stressors (Antonovsky, 1987; Furu, 1991). According to Antonovsky (1987), the ability to cope with stressors in an efficient way consists of the concept "generalised resistance resources". It embraces factors such as money, cognitive ability, ego strength, cultural stability, social support, and so on, which can be related to both individual prerequisites and environmental factors. Such resources make it easier to find reason and meaning in all of the countless stressors that constantly influence individuals. Antonovsky hypothesized that, the stronger the SOC of parents, the more probable it is that they create experiences for their children which are such that the SOC of the child develops in the same direction as the SOC of the parents. Experiences during childhood and adolescence are fundamental for the ability to orientate oneself in the surrounding world and to find life comprehensible, manageable, and meaningful.

Studies supporting these concepts are evident in that the coping style and skill of an adolescent is influenced by family background. Parental discipline styles indicate how children's coping responses reflect parenting style (Edgar, 1998). Emotionally unstable adolescents tend to select a withdrawn coping style which, in turn, tends to lead to poorer adjustment (Schludermann et al., 1996). Coping style, therefore, is a contributor to overall adjustment. From an educational point of view, it is important to increase our knowledge of individual and familial factors influencing the developmental process of coping ability both at home and at school.
There were two purposes of this follow-up study. The first was to investigate genetic influences on experienced family and school environments at adolescence, and on coping ability at 35 years of age by means of conventional twin study correlations. The second was to investigate the relation between coping ability at mid-life and familial, as well as school environments, at adolescence.

\section{Materials and Method \\ Participants}

This investigation is based upon a Swedish longitudinal study, which started in the middle of the 1960s (the SLUstudy). Between 1964 and 1971 a nationally representative sample of monozygotic (MZ) and dizygotic (DZ) twins and a control group of singletons were followed from Grade 3 at 10 years of age to Grade 9 at 16 years of age in the Swedish compulsory school. Originally, $323 \mathrm{MZ}$ and DZ twin pairs, as well as 1193 controls, were included in the sample. At the time of sampling, twin pairs typically attended the same classes. This was true for both MZ and $\mathrm{DZ}$ pairs in this study. As expected, approximately one third were monozygotic pairs, one third dizygotic of the same sex, and one third dizygotic of unlike sex (Ljung et al., 1977). The zygosity classification of the SLU twins has been described by Ljung and colleagues (1977).

The original purpose of this investigation was to study physical and mental growth during puberty, as well as genetic and environmental influences on these growth processes. Several kinds of data were collected, such as physical data (height and weight, menarche, rating of secondary sex characteristics), ability and achievement test results (intelligence tests, standardized achievement tests), ratings by teachers and classmates concerning school adjustment, and socioeconomic background data (father's occupation and income).

When the participants were 35 years old, a follow-up study was initiated. A two-step design was applied. The first questionnaire included questions about participation in a new study, education, occupation, wellbeing, and current health. The questionnaire was sent to all participants from the original study whose postal addresses were accessible (1680 individuals). Seventy-five per cent replied, 1269 individuals. Of these, 155 persons declined to participate in a new study. The loss in the follow-up study, 411 individuals, included individuals who were deceased, had emigrated, or for other reasons did not reply to the questionnaire. Results of this initial questionnaire produced 45\% male and 55\% female response rates (Lange \& Fischbein, 1992), a sex difference consistent with other Swedish longitudinal studies (Furu, 1985).

For the second step of the follow-up study, a questionnaire was sent to a representative sample (900 individuals) of those who had agreed to participate in a new study. We tried to encourage more males to participate, particularly all of the male twins. We sent three reminders, and then made a telephone call. Because of economic limitations, it was not possible to follow the controls to the same extent. The goal was to include 600 individuals, half of them women and half of them men. For each sex, there were to be $50 \%$ twins and $50 \%$ singleton controls. Both twins of a 
pair had to participate for the within-pair comparisons. Furthermore, only individuals with complete data from adolescence were included in the follow-up study. More $\mathrm{DZ}$ than MZ twins were lost because of incomplete data. The resulting sample for this study comprised 320 twins and 322 controls. In spite of our recruitment efforts, more women than men were willing to participate (see Table 1).

The number of complete twin pairs is shown in Table 1. More female than male same-sex twin pairs were included in the follow-up.

\section{Material}

The second questionnaire, which provided the data for this study, dealt with living conditions such as civil status, number of children, housing, education, and present occupation. There also were questions about economy, the frequency of contact (with twin sister/brother, parents, friends and relatives), and earlier family and school environment. The participants reported their present health and coping ability (SOC) as well as experiences of their general life situation. Most of the questions were of multiple choice format.

A main purpose of this study has been to focus on the relation between adolescent and adult life situations. Coping ability at mid-life, therefore, was regarded as the outcome variable. Relations between independent variables such as social class affiliation and retrospective ratings of family situation at adolescence and coping ability in adulthood were examined.

The Family Environment Scale (FES; Moos \& Moos, 1981) was used. Forty of the original ninety items were included in the questionnaire. These were the same items that were used in another longitudinal Swedish twin study, the SATSA-project (Pedersen et al., 1991; Plomin et al., 1988). The items concerning family climate were rated from 1 (agree exactly) to 5 (disagree) and can be assigned to the following areas:

- Cohesion (e.g., Family members really help and support one another.)

- Expressiveness (e.g., There are a lot of spontaneous discussions in our family.)

- Conflict (e.g., We fight a lot in our family.)

- Achievement (e.g., We feel it is important to be the best at whatever you do.)

- Culture (e.g., We rarely go to lectures, plays or concerts.)

- Activities (e.g., Nobody in our family is active in sports, bowling etc.)
- Organization (e.g., We are generally very neat and orderly.)

- Control (e.g., There is a strong emphasis on following rules in our family.)

Questions about parental interest in school (Crumpacker et al., 1979; Garfinkle, 1982) also were a part of the FES included in the questionnaire. The perceived school environment during adolescence was rated by the participants. Respondents gave their opinions concerning school work, teachers, and schoolmates.

Aron Antonovsky's Orientation to Life Questionnaire, the developed scale Sense of Coherence (SOC), has been used to estimate coping ability. The construction and validity of the questionnaire are described in Antonovsky (1987). The questionnaire consists of 29 questions. A short version of this instrument, consisting of 13 questions, was used in the follow-up study. The correlation between the short and long versions is usually found to be approximately $r=.70$ (Antonovsky, 1987; 1993). These versions have been translated into Swedish and validated on a Swedish sample (Furu, 1991). The questions and their 7-point scales are provided in the Appendix. The items were coded so that 1 corresponded to the weakest SOC and 7 to the strongest.

\section{Analyses}

To investigate genetic influences on perceived family and school environment as well as on self-reported coping ability, intraclass correlations by double-entry format for the $\mathrm{MZ}$ and $\mathrm{DZ}$ twin pairs were calculated. The unlike sex twin pairs were especially important for studying sex-specific influences in the same family.

A stepwise linear regression analysis was performed to determine the environmental influences accounting for coping ability. The first of the independent variables introduced in this model was social class affiliation at adolescence. Next, the eight items of the FES and parental interest in school were included. Finally, the perceived school environment was added. This analysis included data collected from males and females of both twins and controls.

\section{Results \\ Genetic Influences}

Genetic influences on coping ability at mid-life were evaluated by comparisons of similarities within $\mathrm{MZ}$ and $\mathrm{DZ}$ twin pairs. Regarding the influence of perceived family environment on coping ability, the FES variables, organization, control and cohesion, are presented in Table 2. The correlations for organization and cohesion, same-sex and unlike sex, show

Table 1

Number of Participants and Complete Twin Pairs by Sex and Zygosity in the Follow-up Study

\begin{tabular}{|c|c|c|c|c|c|}
\hline & $\begin{array}{c}\text { Participants } \\
\text { Male } \\
n\end{array}$ & $\begin{array}{l}\text { Complete pairs } \\
\text { Male } \\
n\end{array}$ & $\begin{array}{c}\text { Participants } \\
\text { Female } \\
n\end{array}$ & $\begin{array}{c}\text { Complete pairs } \\
\text { Female } \\
n\end{array}$ & $\begin{array}{c}\text { Complete pairs } \\
\text { Male/Female } \\
n\end{array}$ \\
\hline $\mathrm{MZ}$ & 41 & 18 & 54 & 25 & \\
\hline $\mathrm{DZ}$ & 104 & 20 & 121 & 31 & 39 \\
\hline Controls & 154 & & 168 & & \\
\hline
\end{tabular}


approximately equivalent magnitude for $\mathrm{MZ}$ and $\mathrm{DZ}$ twins. The unlike sex pairs do not deviate substantially from this pattern. These FES variables provide some evidence for both genes and common environmental effects.

For control, the correlations were very modest for samesex twins but substantially higher for the unlike sex twin pairs. This finding shows no genetic influences but a tendency for males and females to react more similarly. It suggests shared environmental influence. The small sample size has to be taken into consideration, however.

For school environment, that is the SES variable and coping ability that is the SOC variable, MZ twin pairs showed more similarity within the pair than the DZ samesex and unlike sex pairs. The unlike sex pairs yielded zero order correlations within pairs for these variables. These results indicate genetic but no sex-specific influences.

\section{Environmental Influences}

Regarding environmental influences at adolescence on coping ability at mid-life, the regression analysis showed different patterns for males and females. Social class affiliation during adolescence was related to coping ability for males but not for females (Figure 1). High social class affiliation during adolescence was associated with better coping ability for males. However, when the FES variables were introduced into the regression analysis this relation disappeared. Three FES items, organization, control and cohesion, seemed to be of importance. Organization factors within the family predicted coping ability for males but not for females. Perceived control within the family had a negative correlation with coping ability for both males and females. The analysis showed that cohesion within the family at adolescence was positively related to coping ability for males as well as for females. Positive experiences of the school environment at adolescence also were related to coping ability at mid-life for both sexes.

\section{Discussion}

\section{Genetic Influences}

The twin pairs in this follow-up study have made it possible to investigate genetic and sex-specific influences on coping ability, as well as on perceived family and school

\section{Males}

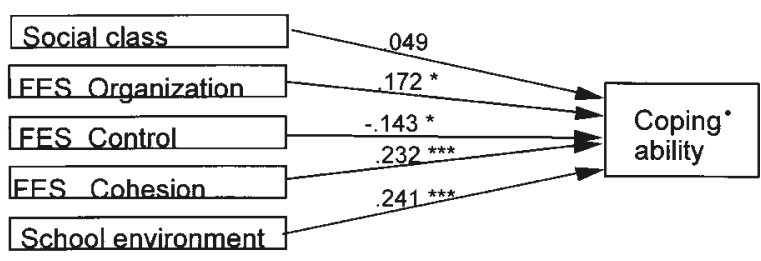

\section{Females}

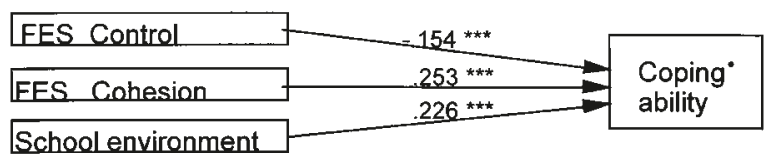

Figure 1

Linear regression analysis for twins and controls regarding environmental influences on coping ability.

Note: ${ }^{*} p<.005 ;{ }^{* * *} p<.001 ; \bullet$ SOC, mean values of 13 questions

environment. Organization and cohesion in the family environment at adolescence showed a modest genetic influence, while the control variable gave no evidence of such influences but a fairly high concordance for unlike sex pairs. Because home environment can be assumed to be more differentiated than school environment, it may be why the $M Z$ twins within pairs had experienced their school environment more similarly than the DZ twin pairs. In another Swedish twin study (Fischbein et al., 1990) it was found that teachers did not differentiate between $\mathrm{MZ}$ twins, so that $\mathrm{MZ}$ co-twins perceived themselves being treated more similarly than did DZ co-twins. Because $M Z$ twins look alike, teachers have difficulty distinguishing them from each other, thereby treating

Table 2

Intraclass Correlations for MZ and DZ Twin Pairs Regarding Perceived Family and School Environment as well as Coping Ability

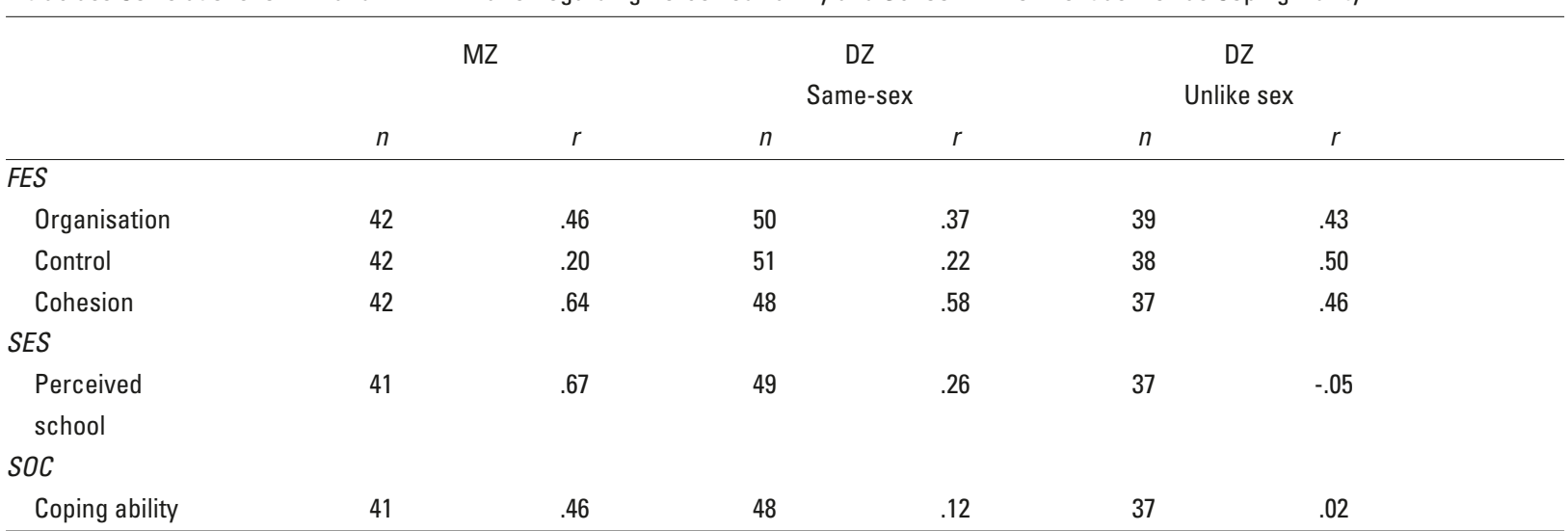


them more similarly than they treat DZ twins (Alin Åkerman et al., 1997).

The ability to understand and handle problems varies from individual to individual. The development of coping ability is related to experiences during childhood and early adult life (Antonovsky, 1987). Developmental potential seems to be somewhat dependent on genetic factors, however. MZ twins show moderate similarity within pairs regarding coping ability. Within DZ twin pairs there is, on the whole, negligible resemblance, both for the same and for the opposite sex pairs.

\section{Environmental Influences}

Perceived family and school influences on coping ability at the age of 35 have been investigated in a regression analysis. Results in this follow-up study seem to indicate that early environmental influences have a long-term effect.

It should be noted that both social class affiliation at adolescence and retrospective ratings of family and school environments were used. An adult who handles mid-life experiences successfully might have a rosier memory of childhood than one who encounters difficulties. On the other hand, adult ratings of earlier family and school environment make it possible to reflect upon the course of events and processes that occurred during adolescence in a balanced and thoughtful way.

The development of coping ability at the age of 35 was influenced by different kinds of environmental factors for males and females. Males who belonged to a higher social class at adolescence seemed to be more competent at coping with problems at adult age compared to males of a lower social class. This was not found for females. Family climate could reduce the effect of this variable for males. A family environment based on structure with a firm organization and order also was positive for males regarding coping ability.

Some environmental influences tended to have the same effect for both males and females. Cohesion within the family during adolescence was significant for both males and females in relation to coping ability at mid-life. It is assumed that the feeling of cohesion within the family includes a stimulating atmosphere that supports optimal development (Fischbein, 1979). Positive and continuous social relations within the family, therefore, seem to be of vital importance. These influences have been called proximal processes by Bronfenbrenner and Ceci, (1994). Manetti and Migliorini (1996) also have suggested that students with strong support from the family present more positive coping strategies.

Perceived control within the family had a negative correlation with the development of coping ability for both sexes. A restrictive family environment seems to limit individual prerequisites to develop adequate coping strategies. This implies that the more control there is within the family, the worse the development of coping ability for the individual. Excessive parental control has been found in other studies to be associated with maladaptive behaviors in children (Aunola et al., in press). These results also are in agreement with recent findings by Stattin and Kerr (2000) who stressed the importance of child disclosure in parental monitoring. This means, of course, that monitoring cannot be a one-sided activity but has to rely on a mutual relationship between parent and child (e.g., proximal processes). Communication patterns within families, therefore, seem to be of vital importance.

Positive experiences in the school environment during adolescence promote coping ability at the age of 35 . Perceived cohesion with classmates at school can provide a stimulating environment in which the ability to cope with problems is supported. In a stimulating environment individual prerequisites can be activated and developed more optimally in accordance with the choice of the individual. At home and at school there are possibilities to organize situations where the interplay between the prerequisites of the individual and environmental factors occurs with the purpose of training in coping ability. Structural factors seem to be more decisive for males, whereas cohesion and cooperation are important for both males and females.

\section{Interactional Effects}

Neither environment nor heredity is the sole contributor to individual development. There is an interaction, even if some variables may be influenced more by one than the other. In accordance with earlier results (Bronfenbrenner \& Ceci, 1994; Fischbein, 1979) the follow-up suggests that development depends on how individual predispositions interact with the environment. Here it should be noted that environmental factors can change over time. The variation of development is influenced by the atmosphere of the surrounding environment. Individuals construct different experiences from the same environmental opportunities, based on their prior experiences and on their dispositional genotypes (Scarr, 1993). It is important to increase knowledge about factors contributing to the development of coping ability. Bronfenbrenner and Ceci (1994) express this in their bioecological theory in which development is hypothesized to be dependent upon proximal processes. These processes can be compared to the importance of positive relations in the family and school environment. Baumrind (1993) and Antonovsky (1987) also emphasize the importance of parental influences.

The conclusion of this study is that both early environmental factors and genetic factors have long-term effects on coping ability. In the interaction between genes and environment, both the individual and the environment are influenced by and influence each other. Environmental factors and, above all, positive, continuous social relations are important for the optimal development of coping ability (Fischbein, 1998; Lange, 1996; 2000). The expression of these environmental factors and the experience of what is stimulating appear to be different for males and females. Environmental influences can be directed toward a definite goal. For parents and persons who work with children and young people, knowledge and awareness of environmental structure, support, and stimulation are needed to accomplish this goal. In view of the excessive number of females working in preschool and school it is especially interesting to reflect on the consequences for boys. They might have a greater need for structure expressiveness and if this is not given it might be one reason for the excessive number of boys in special education. 


\section{Acknowledgments}

The follow-up of the SLU-study has been supported by grants from the Swedish Council for Social Research (SFR) and Penn State University. The author wishes to thank Marilyn Riese and Richard Rose as well as Siv Fischbein for their valuable advice and comments in reviewing the manuscript. I also express my gratitude to Anders Skarlind for aiding in the preparation of the manuscript.

\section{References}

Alin Åkerman, B., \& Fischbein, S. (1991). A longitudinal study of twins and non-twins from birth to 18 years of age. Acta Geneticae Medicae et Gemellologiae, 40, 29-40.

Alin Åkerman, B., Thomassen, P. A., \& Winbladh, B. (1997). Par i barn Tvillingar och trillingar frän foster till tonaring (Pair of children Twins and triplets from foetus to teenager). Stockholm: Natur och Kultur.

Antonovsky, A. (1987). Unraveling the mystery of health. How people manage stress and stay well. San Francisco: Jossey-Bass Publishers.

Antonovsky, A. (1993). The structure and properties of the sense of coherence scale. Social Science and Medicine, 36, 725-733.

Aunola, K., Stattin, H., \& Nurmi, J-E. (in press). Parenting styles and adolescents' achievementstrategies. Journal of Adolescence.

Baumrind, D. (1993). The average expectable environment is not good enough: A response to Scarr. Child Development, 64, 1299-1317.

Bergman, L. R. (1978). Utveckling av könsskillnader i skolprestation mellan 10 och 15 ars alder (Development of sex differences in school achievements between 10 and 15 years of age; Rapport No. 24). Stockholm: Department of Psychology, University of Stockholm.

Bronfenbrenner, U., \& Ceci, S. J. (1994) Nature-nuture reconceptualized in developmental perspective: A bioecological model. Psychological Review, 101, 4, 568-586.

Crumpacker, D. W., Cederlöf, R., Friberg, L., Kimberling, W. J., Sörensen, S., Vandenberg, S. G., et al. (1979). A twin methodology for the study of genetic and environmental control of variation in human smoking behaviour. Acta Geneticae Medicae et Gemellologiae, 28, 173-195.

Edgar, D. (1998). Families as the crucible of competence in a changing social ecology. In E. Frydenberg (Ed.), Learning to cope. Developing as a person in complex societies. Oxford: Oxford University Press.

Fischbein, S. (1978). Heredity-environment interaction in the development of twins. International Journal of Behavioural Development, 1, 313-322.

Fischbein, S. (1979). Heredity-environment influences on growth and development during adolescence. Lund: Liber.

Fischbein, S., Guttman, R., Nathan, M., \& Esrachi, A. (1990). Permissiveness-restrictiveness for twins and controls in two educational settings: The Swedish compulsory school and the Israeli kibbutz. Acta Geneticae Medicae et Gemellologiae, 39, 245-257.

Fischbein, S. (1998, June). Developmental variation in relation to environmental structure and stimulation. Presentation at the 9th International Congress on Twin Studies, Helsinki, Finland.

Furu, M. (1985). Life patterns and health. A longitudinal study of men from childhood to middle age. Malmö: Liber.
Furu, M. (1991). Livsmönster och Hälsa. Känsla av sammanhang i tillvaron - teoretisk bakgrund och mätmetod. (Life patterns and health. Sense of coherence - theoretical background and method of measurement). Stockholm: Institute of Education, Department of Educational Research.

Garfinkle, A. S. (1982). Genetic and environmental influences on the development of Piagetian logico-mathematical concepts and other specific cognitive abilities: A twin study. Acta Geneticae Medicae et Gemellologiae, 28, 173-195.

Lange, A-L., \& Fischbein, S. (1992). From puberty to mid-life: A follow-up study of twins and controls. Acta Geneticae Medicae et Gemellologiae, 41, 105-112.

Lange, A-L. (1996). Från uppväxttid till vuxenliv (From adolescence to adult; Rapport). Stockholm: Department of Special Education, Stockholm Institute of Education.

Lange, A-L. (2000). From child to adult (Studies in Educational Sciences 28). Stockholm: Stockholm Institute of Education Press.

Ljung, B-O., Fischbein, S., \& Lindgren, G. (1977). A comparison of growth in twins and singleton controls of matched age followed longitudinal from 10 to 18 years. Annals of Human Biology, 4(5), 405-415.

Manetti, M., \& Migliorini, L. (1996). Social support, coping strategies and outcomes in University students. Poster presented at the 14th ISSBD Conference in Quebec City, Canada.

Moos, R. H., \& Moos, B. S. (1981). Family Environment Scale manual. Palo Alto, CA: Consulting Psychologists Press.

Nordberg, L. (1994). The first four years of children's mental development. An emperical study with applications in psychology, child-and adolescence psychiatry and pediatrics. Stockholm: Gotab.

Pedersen, N. L., McClearn, G. E., Plomin, R., Nesselroade, J. R., Berg, S., \& de Faire, U. (1991). The Swedish Adoption/Twin Study of Aging: An update. Acta Geneticae Medicae et Gemellologiae, 40, 7-20.

Plomin, R., McClearn, G. E., Pedersen, N., Nesselroade, J. R., \& Bergeman, C. S. (1988). Genetic influence on childhood family environment perceived retrospectively from the last half of the life span. Developmental Psychology, 24(5), $738-745$.

Scarr, S. (1992). Developmental theories for the 1990s: Development and individual differences. Child Development, 63, 1-19.

Scarr, S. (1993). Biological and cultural diversity: The legacy of Darwin for development. Child Development, 64, 1333-1353.

Schludermann, S., Schludermann, E., \& Huynh, C-L. (1996) Family background, adolescent coping styles and adjustment. Poster presented at the 14th ISSBD Conference Québec City, Canada. Department of Psychology, University of Manitoba Winnipeg, MB, Canada.

Stattin, H., \& Kerr, M. (2000). Parental monitoring: A reinterpretation. Child Development, 71, 1072-1085.

Sundelin Wahlsten, V. (1991). Utveckling och överlevnad. En studie av barn i psykosociala riskmiljöer (Development and survival. A study of children in psychosocial risk environment). Stockholm: Department of Education, University of Stockholm.

Tanner, J. M. (1978). Foetus into man. London: Open Books.

Westin-Lindgren, G. (1979). Physical and mental development in Swedish urban schoolchildren. Lund: Liber. 


\section{Appendix}

After Antonovsky (1987), the short version of Orientation to Life Questionnaire

1. Do you have the feeling that you don't really care about what goes on around you?

$$
1 \text { - very seldom or never } \quad 7 \text { - very often }
$$

2. Has it happened in the past that you were surprised by the behavior of people whom you thought you knew well?

$$
1 \text { - never happened } 7 \text { - always happened }
$$

3. Has it happened that people who you counted on disappointed you?

$$
1 \text { - never happened }
$$

$$
7 \text { - always happened }
$$

4. Until now your life has had:

$$
1 \text { - no clear goals or purpose at all } \quad 7 \text { - very clear goals and purpose }
$$

5. Do you have the feeling that you're being treated unfairly?

$$
1 \text { - very often } \quad 7 \text { - very seldom or never }
$$

6. Do you have the feeling that you are in an unfamiliar situation and don't know what to do? 1 - very often

7 - very seldom or never

7. Doing the things you do every day is:

$$
1 \text { - a source of deep pleasure and satisfaction }
$$

7 - a source of pain and boredom

8. Do you have very mixed-up feelings and ideas?

1 - very often

$$
7 \text { - very seldom or never }
$$

9. Does it happen that you have feelings inside you would rather not feel?

$$
1 \text { - very often }
$$

7 - very seldom or never

10. Many people — even those with a strong character — sometimes feel sacks (losers) in certain situations. How often have you felt this way in the past?

$$
1 \text { - never } \quad 7 \text { - very often }
$$

11. When something happened, have you generally found that: 1 - you overestimated or underestimated its importance $\quad 7$ - you saw things in the right proportion

12. How often do you have the feeling that there's little meaning in the things you do in your daily life? 1 - very often 7 - very seldom or never

13. How often do you have feelings that you're not sure you can keep under control? 1 - very often

7 - very seldom or never 